\title{
Intergluteal Cleft Eccrine Porocarcinoma with Metastasis to Inguinal Region and Lung: Case Report and Review of the Literature
}

\author{
Ricardo Fernández-Ferreira ${ }^{a}$ Gabriela Alvarado-Luna ${ }^{a}$ \\ Daniel Motola-Kuba a Ileana Mackinney-Noveloa \\ Eduardo Emir Cervera-Ceballos ${ }^{a}$ Román Segura-Rivera ${ }^{b}$ \\ ancology Medicine Department, Comprehensive Oncology Center "Diana Laura Riojas \\ de Colosio," Medica Sur Clinic \& Foundation, Mexico City, Mexico; 'bervice of Anatomical \\ Pathology, Medica Sur Clinic \& Foundation, Mexico City, Mexico
}

\author{
Keywords \\ Intergluteal cleft · Eccrine porocarcinoma · Metastasis · Chemotherapy
}

\begin{abstract}
Eccrine porocarcinoma (EPC) is an infrequent cutaneous neoplasm, and was described in 1963 by Pinkus and Mehregan. It is a rare type of skin tumor $(0.005-0.01 \%$ of all skin tumors). Less than 300 cases have been described in the entire world medical literature. To our knowledge, no case of intergluteal cleft EPC has been reported in the literature in English and Spanish to date, so this would be the first reported case of such pathology. Metastatic EPC is less frequent, since only $<10 \%$ of metastatic type have been reported and the rest as localized disease. The primary treatment of choice is surgical wide local excision of the tumor with histological confirmation of tumor-free margins. Prognosis is difficult to determine because of the rarity of EPC and the variations in natural history. There are no data to support the use of adjuvant chemotherapy or radiotherapy, and there are currently no agreed criteria to define patients at high risk of relapse. We present a 67-year-old man with intergluteal cleft eccrine tumor by biopsy. Metastasis to left inguinal region and lung was reported by contrasted abdominal and chest computed tomography. He started chemotherapy based on etoposide, vincristine, carboplatin. A review of pertinent literature is provided.
\end{abstract}




\section{Introduction}

Eccrine porocarcinoma (EPC) is an infrequent cutaneous neoplasm, which derives from the eccrine sweat glands and was described in 1963 by Pinkus and Mehregan [1]. It is a rare type of skin tumor $(0.005-0.01 \%$ of all skin tumors). It is located more frequently in the lower extremities (44\%), other common sites are the trunk (24\%) and head (18\%) in elderly patients with a slight predominance in women $[2,3]$. This tumor can appear de novo or as a progression of a benign poroma, of very slow growth in its onset that after its malignancy, its behavior is aggressive, with rapid growth. Macroscopically, EPC can appear as a nodule, a polypoid ulcerating lesion, or a plaque with an infiltrative or erosive pattern $[2,4]$.

Less than 300 cases have been described in the entire world medical literature, with incidence being rare in Europe. $20 \%$ of these tumors recur, $10 \%$ metastasize to solid organs and $20 \%$ to regional lymph nodes and can have epidermotropic pagetoid diffusion, with a mortality rate of almost $70 \%$ in the latter $[2,5,6]$.

The treatment of this type of tumor has been through extensive surgical excision, Mohs surgery, or radiotherapy. Surgical treatment is curative in $80 \%$ of non-metastatic cases $[7,8]$. Chemotherapy is reserved for the treatment of metastatic EPC, there are no standard protocols, and there are varying degrees of response $[9,10]$. The radiation is of little benefit, leaving for palliative care since the response is partial. The role of sentinel lymph node biopsy is unknown, and prophylactic lymphadenectomy is controversial [11].

To the best of our knowledge, no cases of intergluteal cleft EPC have been reported in the English-language literature to date. We report a new rare case of a 67-year-old man affected by an intergluteal cleft EPC, with inguinal and lung metastasis. We discuss the clinical presentation and the histopathological findings and review the literature.

\section{Case Report}

A 67-year-old man presented with a mass on the intergluteal cleft and lymphadenopathy in both inguinal regions. There was no history of pain, fever, malaise, nausea, vomiting, constipation, bloody diarrhea, or abdominal distension. Past medical history included Systemic arterial hypertension in treatment. He first noticed it 1 year before and it had progressively increased in size to $2.5 \times 2.5 \mathrm{~cm}$. The mass was soft, non-tender, and freely mobile in the subcutaneous tissue with normal-appearing overlying skin. Examination revealed bilateral inguinal lymphadenopathy (right of $1 \mathrm{~cm}$ and a ganglionic conglomerates of $4.5 \times 7 \mathrm{~cm}$ in left inguinal region). Mohs surgery was performed, and a tumor and ganglion biopsy was taken, histopathological examination revealed high-grade malignancy of primary cutaneous appendages of skin with basaloid differentiation of squamous cells, glandular and alveolar tubule, in some areas myxoid degeneration, microcalcifications, lymphatic and vascular permeation; the tumor was less than $1 \mathrm{~mm}$ from the edges of the section and from the surgical bed and ganglion right inguinal lymphatic with metastasis of malignant neoplasm mixed with high skin grade (Fig.1 and 2).

An abdominal computed tomography (CT) with intravenous contrast was performed in which a solid tumor lesion in intergluteal cleft of $2.3 \mathrm{~cm}$, as well as a giant adenopathy in left inguinal region ( $4.5 \mathrm{~cm}$ conglomerate) was reported. Contrast chest CT reported bilateral pulmonary nodules (right $6.4 \mathrm{~mm}$ and left basal $1.1 \mathrm{~cm}$ ) and bilateral axillary and cervical adenopathies. The diagnosis was EPC with areas of epidermoid, basal cell and sebaceous differentiation. No perineural lymphatic invasion, lymph node with carcinoma metastasis (Fig.1 and 2). He started chemotherapy based on etoposide, vincristine, carboplatin.

\section{Karger'}




\section{Case Reports in Oncology}

\begin{tabular}{l|l}
\hline Case Rep Oncol 2020;13:1463-1473 \\
\hline DOI: 10.1159/000510311 & $\begin{array}{l}\text { @ 2020 The Author(s). Published by S. Karger AG, Basel } \\
\text { www.karger.com/cro }\end{array}$ \\
\hline
\end{tabular}

Fernández-Ferreira et al.: Intergluteal Cleft Eccrine Porocarcinoma with Metastasis to Inguinal Region and Lung
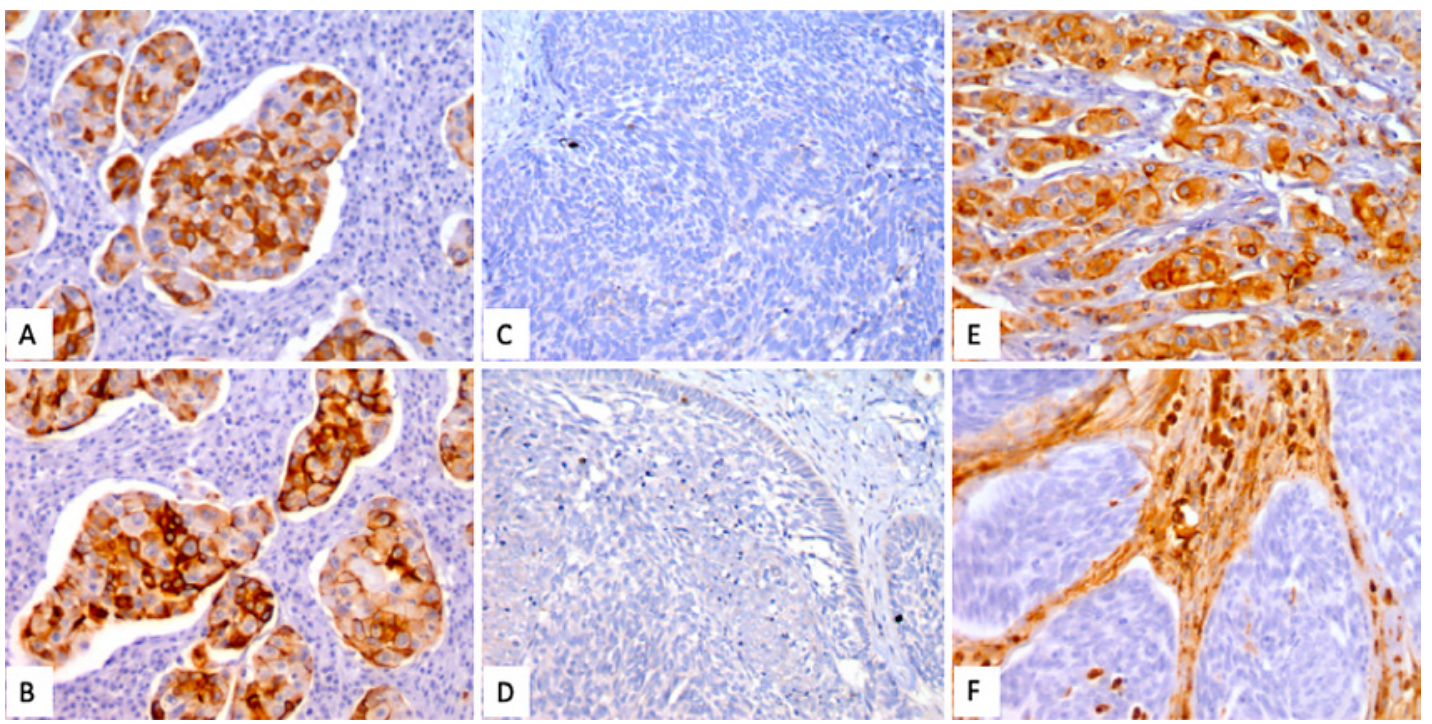

Fig. 1. Immunohistochemistry: In spite of the different morphologies, most of the cells showed reactivity to immunostains with AE1/3, CK7 (A) and CK19 (B), which confirms their epithelial lineage. The spindle cell areas were negative for vimentin (E, F), which only marked the accompanying stroma. Chromogranin $(\mathbf{C})$ and synaptophysin (D) were also negative.

Fig. 2. Hematoxylin \& eosin: Some of the tumoral nests show clearing of the cytoplasm, with a foamy appearance and with small vacuolar formations. (A) The zones with eccrine differentiation (B) show ductular formation with mucoid content. Other areas exhibit squamous differentiation (C), whose cells are large, with broad and eosinophilic cytoplasm. Histologically, the neoplasm is heterogeneous, composed predominantly of compact nests of small, basaloid cells (D) with scant cytoplasm; some of these cells displayed mild spindling.

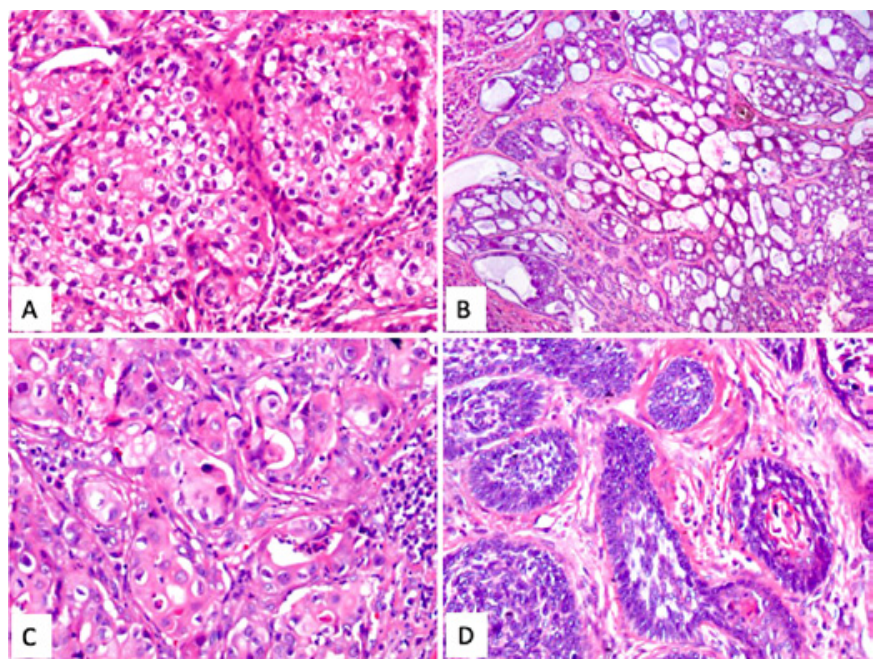

\section{Discussion}

EPC, also known as malignant eccrine poroma, forms in the intraepidermic ductal portion of the sweat gland and was first described by Pinkus and Mehregan in 1963, who used the term epidermotropic eccrine carcinoma as the tumor arises from the intraepidermal portion of the eccrine sweat glands [1]. The term EPC was introduced by Mishima and Morioka in 1969 , since then fewer than $300 \mathrm{EPC}$ cases have been reported worldwide $[2,5,12]$. This rare malignant adnexal tumor has been termed as malignant hidroacanthoma simplex, malignant intra epithelial eccrine poroma, eccrine poroepithelioma, malignant syringoacanthoma, dysplastic poroma, and sweat gland carcinoma [13-15]. 
It is a rare tumor, representing only $0.005-0.01 \%$ of all malignant epithelial neoplasms. However Goon et al. [16] showed that EPC diagnosis, although rare, has been rising in the East of England, and has risen rapidly over the last 10 years, possibly due to histological diagnostic factors, and more precise registration together with a possible real increase in incidence [2, 4].

The majority of the patients are older, with a peak incidence at 67 years of age (mean age 74 years), but it can affect children or young adults. Although it does not seem to have a predilection for sex or race, some studies indicate a slight prevalence in women. The exact etiology of EPC is unclear. Some authors suggested a possible association with radiation exposure and immunosuppression, although an excessive sun exposure does not seem to be a significant risk factor [17-19].

EPC arises most commonly (33-50\%) on the lower extremities, but can also be found in other cases series in 18\%, followed by the trunk (14.7-24\%), head and neck (23-32\%), upper extremities (7.4-11\%), genitalia/buttocks $(<11 \%)$, and rarely involves other areas (e.g., scalp $<5 \%$, lips, mandibule, nose, occiput, parietal, parieto-occipital, preauricular, temporomandibular, temporoparietal, crus, thorax, flank, breast, axilla, finger, hand, palm, shoulder, calf, heel, knee, sole, tibia, toe, mons pubis, prepuce, penis, scrotum, inguinal, vulva, etc.) $[2,4,5$, $8,13,15,18-58]$.

In Mexico, Riera-Leal et al. [4], reported 33 cases, the most frequent localization was the head (37\%), followed by the trunk (30\%), upper extremities (15\%), lower extremities (18\%). As to the clinical form, the most frequently observed was nodular (46\%), followed by exophytic tumor $(21 \%)$. This contrasts with reports from other authors, who mention that polypoid or ulcerated tumors were the most common form. Other reported forms of presentation include verrucous plaque similar to a cauliflower, firm erythematous-violaceous nodule, zosteriform variant, such as reticulated erythema, carcinomatous lymphangitis with lymphedema and mimicking a venous leg ulcer $[21,59,60]$.

The size can also vary from less than $1 \mathrm{~cm}$ to up to $10 \mathrm{~cm}$ in diameter, with a $2.4 \mathrm{~cm}$ average $[4,34]$. The low degree of clinical suspicion of EPC could be due to the low incidence rate, non-specific macroscopic appearance, and vague dermoscopic pattern of neovascularization. As a result, the diagnosis and appropriate treatment are often delayed, thereby providing time for the cancer to spread throughout the body, with lethal consequences [61]. Histopathologically, metastatic adenocarcinoma, trabecular carcinoma, Merkel cell carcinoma, benign nevi, warts, angiomas, clear cell hidradenocarcinoma, basal cell carcinoma, squamous cell carcinoma, seborrheic keratosis, amelanotic melanoma, and verruca vulgaris should be considered as some of the differential diagnoses. Later, as their growth accelerates, these lesions are submitted to biopsy to reveal the correct diagnosis [2, 4, 5, 18-20, 60-62].

EPCs are histologically diverse; however, common characteristics on hematoxylin \& eosin staining include nuclear atypia, increased mitotic activity, and necrosis [20,63]. From the histopathological point of view, the tumor is characterized by pleomorphic cells with nuclear hyperchromasia and important mitotic activity, surrounded by ductal lumen. It can be intraepidermal, an in situ variation, grows horizontally, and produces an extensive pagetoid infiltrate. This epidermotropic or intraepidermal type has been reported to have local recurrences. The invasive dermal type usually presents as nodular aggregates associated with a broad deep margin pushing down into the dermis (pushing type) or with an infiltrative growth pattern (infiltrative type) [64]. Immunohistochemical stains used for the diagnosis of EPC include carcinoembryonic antigen, cytokeratin (CK) (pan-CK and CK5/6), epithelial membrane antigen, p53, and p63 [12, 65]. In addition, a recent study by Mahalingam et al. [65] showed that the diagnostic sensitivity and specificity for EPC significantly improved by using a selected panel of stains including CK7, CK19 (specificity, 82\%), and nestin. Little is known about metastatic cutaneous adnexal neoplasms, but it seems that $\mathrm{p} 63$ continues to be 
Table 1. Eccrine carcinoma pathological stages

Eccrine carcinoma pathological stages (pTNM)

pTX: Primary tumor not assessable

pT0: No evidence of primary tumor

pTis: Carcinoma in situ

pT1: Tumor $2 \mathrm{~cm}$ or less in the largest dimension

- pT1a: Limited to the dermis or $2 \mathrm{~mm}$ or less in thickness

- pT1b: Limited to the dermis and more than $2 \mathrm{~mm}$ in thickness, but not more than $6 \mathrm{~mm}$ in thickness

- pT1c: Invading the subcutis and/or more than $6 \mathrm{~mm}$ in thickness

pT2: Tumor greater than $2 \mathrm{~cm}$ but not more than $5 \mathrm{~cm}$ in its greatest dimension

- pT2a: Limited to the dermis or $2 \mathrm{~mm}$ or less in thickness

- pT2b: Limited to the dermis and more than $2 \mathrm{~mm}$ in thickness but not more than $6 \mathrm{~mm}$ in thickness

- pT2c: Invading the subcutis and/or more than $6 \mathrm{~mm}$ in thickness

pT3: Tumor over $5 \mathrm{~cm}$ in its greatest dimension

- pT3a: Limited to the dermis or $2 \mathrm{~mm}$ or less in thickness

- pT3b: Limited to the dermis and more than $2 \mathrm{~mm}$ in thickness, but not more than $6 \mathrm{~mm}$ in thickness

- pT3c: Invading the subcutis and/or more than $6 \mathrm{~mm}$ in thickness

pT4: Tumor invades the deep extradermal tissue (e.g., cartilage, skeletal muscle, bone)

- pT4a: $6 \mathrm{~mm}$ or less in thickness

- pT4b: More than $6 \mathrm{~mm}$ in thickness

Regional lymph nodes ( $\mathrm{pN}$ )

- pNX: Regional lymph nodes not assessable

- pN0: No regional lymph node metastasis

- pN1: Regional lymph node metastasis

Distant metastasis (pM)

- pMX: Presence of distant metastasis not assessable

- pM1: Distant metastasis

expressed in these tumors, thus making their histological differentiation from metastatic adenocarcinomas to the skin potentially easier [66]. Expression of p53 protein may have a role in the carcinogenesis of EPC. The time to malignant transformation of a benign poroma is highly variable and can range from months to decades. A long period of clinical history is often encountered (up to 50 years), but rapid development within few months has also been reported [67].

Radiology may be useful for surgical planning and evaluation of regional or distant metastasis, including the detection of occult metastases. Ultrasound, CT, or magnetic resonance imaging of the regional lymph node basins should be considered for primary tumors on the trunk, extremities, and genitalia. PET (positron emission tomography)/CT scan might be considered in these patients. In addition, a mitotic index of more than 14 mitotic cells per 10 high-power fields, lymphovascular invasion, and a tumor depth exceeding $7 \mathrm{~mm}$ and poorly differentiated tumor may suggest the need for diagnostic imaging and often predict a worse prognosis [20,65].

An interesting detail is the fact that certain clinical data have been reported as suggestive of poor prognosis, such as presence of ulceration, sudden growth in a few months, spontaneous bleeding, pain, multinodularity, and pruritis. Organ spreading is only found occasionally, but with a very poor prognosis [68].

Invasive porocarcinoma shows extensive growth of cords or bands of polygonal tumorous cells with pleomorphic nuclei that proliferate asymmetrically inside the dermis with a large quantity of mitotic figures and necrotic areas with multiple ductal structures (90\%). EPC often takes an aggressive clinical course. When invasive porocarcinoma affects the lymphatic 


\section{Case Reports in Oncology}

Fernández-Ferreira et al.: Intergluteal Cleft Eccrine Porocarcinoma with Metastasis to Inguinal Region and Lung

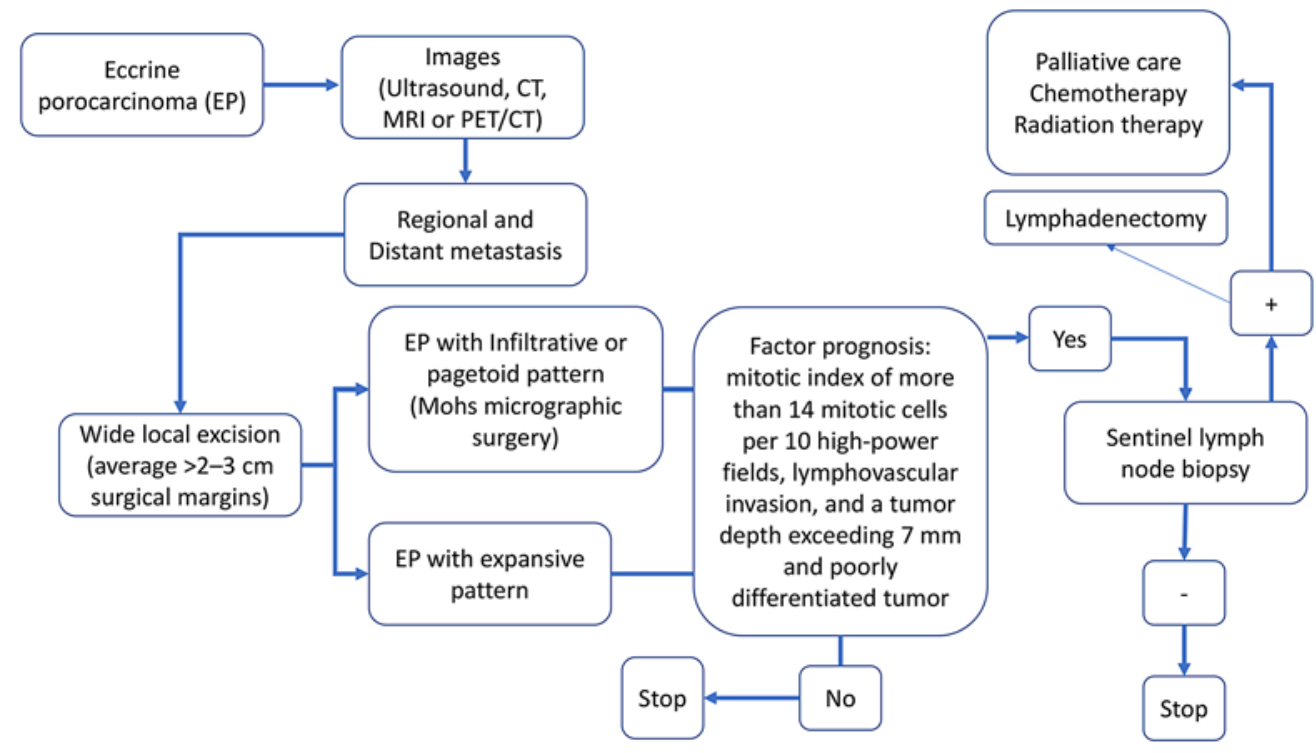

Fig. 3. Diagnostic and treatment algorithm followed in the series presented and based on the literature reviewed.

vessels, it reinvades the epidermis, which would explain the cutaneous metastasis, with a $20 \%$ rate of local recurrence, whereas distant metastasis occurs in approximately $10 \%$. This lymphatic vessel invasion is rare, reported as present only in $15-20 \%$ of the cases however in patients with lymph node metastases, the mortality rate is high at $67 \%$. The incidence of widespread cutaneous metastasis is unknown. According to other authors, this feature is unusual, and only 9 well-described case reports have been published. Multiple cutaneous metastases may develop or less commonly metastases occur in lung, retro-peritoneum, bone, liver, breast, bladder, peritoneum, or ovary $[2,5,6,9,10,18,61,69-74]$. For eccrine carcinoma staging, see Table 1.

\section{Treatment}

According to what is reported in the literature, the diagnostic and treatment approach of EPC should be as shown in Figure 3.

The treatment of choice for a confirmed EPC is a wide local excision of the primary tumor, with curative rates from 70 to $80 \%$ of cases. Wide local excision (average $>2-3 \mathrm{~cm}$ surgical margins) has been shown to have a $20 \%$ local recurrence rate, despite confirmation of clear margins from the primary excision [18, 75-80]. In cases of more infiltrative carcinoma, surgical resection should be performed with histological confirmation of the tumor-free margins by micrographic control of surgical margins, for example Mohs micrographic surgery. However, the size of the margins has not been clearly elucidated [7, 76, 81-83].

Sentinel lymph node sampling is controversial but may be helpful for prognosis in cases of thick tumors or with high mitotic rates. Thus, sentinel lymph node biopsy is recommended only in special cases such as those with aggressive tumor types, associated lymphadenopathy, or a depth of over $7 \mathrm{~mm}$. Some authors have also advocated elective lymphadenectomy, but its clinical value remains controversial. Only radical lymphadenectomy of the affected territory will be performed if the sentinel lymph node biopsy is positive [2, 68, 83-87]. 
Table 2. General characteristics, treatment (surgical resection, radiation therapy, and chemotherapy), objective response, or global survival of metastatic EPC after chemotherapy

\begin{tabular}{|c|c|c|c|c|c|c|c|c|c|}
\hline First author & $\begin{array}{l}\text { Age, } \\
\text { years }\end{array}$ & Sex & Site & $\begin{array}{l}\text { Size, } \\
\mathrm{mm}\end{array}$ & $\begin{array}{l}\text { Lymph } \\
\text { node/ } \\
\text { distant } \\
\text { metastasis }\end{array}$ & $\begin{array}{l}\text { Surgical } \\
\text { resection }\end{array}$ & $\begin{array}{l}\text { Radiation } \\
\text { therapy }\end{array}$ & Chemotherapy & $\begin{array}{l}\text { Overall } \\
\text { survival, } \\
\text { months }\end{array}$ \\
\hline Kurashige, 2013 & 50 & M & Left arm & 80 & + & + & 21 Gy & Docetaxel + cisplatin & 8 \\
\hline Mandaliya, 2016 & 66 & $\mathrm{~F}$ & Right forearm & - & + & + & 50 Gy & Docetaxel + cisplatin & $\begin{array}{l}\text { Complete } \\
\text { Response }\end{array}$ \\
\hline Godillot, 2018 & 64 & $\mathrm{~F}$ & Pubic & 50 & + & + & 57 Gy & Cetuximab + paclitaxel & $\begin{array}{l}\text { Complete } \\
\text { response }\end{array}$ \\
\hline Ishida, 2011 & 72 & M & Right thigh & 17 & + & + & - & Carboplatin and farmorubicin & 8 \\
\hline Joseph, 2015 & 56 & M & $\begin{array}{l}\text { Anterior } \\
\text { abdominal wall }\end{array}$ & 100 & + & - & - & $\begin{array}{l}\text { Doxorubicin, mitomycin, vincristine, } \\
\text { and 5-FU, bleomycin, paclitaxel, } \\
\text { carboplatin, and docetaxel }\end{array}$ & 14 \\
\hline Kim, 2007 & 42 & M & Right palm & - & + & + & + & $\begin{array}{l}\text { Cyclophosphamide, cisplatin, and } \\
\text { doxorubicin }\end{array}$ & 3 \\
\hline Grimme, 1999 & 47 & M & Head & 15 & + & + & 45 Gy & $\begin{array}{l}\text { Bleomycin, 5-fluorouracil, } \\
\text { carboplatin, interferon-alpha, and IL2 }\end{array}$ & 6 \\
\hline Shiohara, 2007 & 62 & $\mathrm{~F}$ & Head & 98 & + & + & 50 Gy & $\begin{array}{l}\text { Cisplatin, adriamycin, VDS/ } \\
\text { mitomycin, vincristine, and epirubicin }\end{array}$ & 35 \\
\hline Permal, 2000 & 67 & $\mathrm{~F}$ & Left thigh & 150 & + & + & - & Tamoxifen & 1 \\
\hline Gonzalez, 2003 & 71 & M & Right thigh & 40 & + & + & 60 Gy & Isotretinoin and tegafur & 66 \\
\hline Plunkett, 2001 & 45 & $\mathrm{~F}$ & Left shoulder & 10 & + & + & BERT & Epirubicin and docetaxel & 9 \\
\hline Swanson, 1989 & 78 & M & Left shoulder & - & + & + & + & Continuous infusion 5-fluorouracil & $\begin{array}{l}\text { Complete } \\
\text { response }\end{array}$ \\
\hline De Bree, 2005 & 69 & M & Left thigh & 150 & + & + & - & $\begin{array}{l}\text { Topical application of } 3 \% \\
\text { 5-fluorouracil ointment, and } \\
\text { docetaxel }\end{array}$ & 25 \\
\hline Gutermuth, 2004 & 67 & M & Left neck & 100 & + & + & - & Interferon-alpha and paclitaxel & 7 \\
\hline
\end{tabular}

While initial surgical treatment is curative for most of the cases, no standard treatment protocols exist for metastatic EPC. In the largest series of 24 evaluated patients with metastatic eccrine sweat gland carcinomas, the best results were achieved with combinations of cyclophosphamide, bleomycin, cisplatin, and 5-FU, leading to partial remissions lasting 5-8 months. Partial remissions lasting 2-4 months were achieved by combining cyclophosphamide, vincristine, and prednisone. Different therapeutic regimens have been proposed with varying results (Table 2). Among these, taxane-based regimens have been proposed for $50 \%$ of cases and have shown therapeutic efficacy [9, 88-104].

Single-agent or multi-agent chemotherapy with isotretinoin, interferon alfa, radiation therapy (usually as adjuvant postoperative palliative care), and electroporation (intralesional chemotherapy) have also been reported as being well tolerated but with varying responses [9-11, 64, 98, 99]. An electrochemotherapeutic approach for local recurrency or cutaneous metastases has been described, while radiation therapy is of little benefit [6]. 


\section{Case Reports in Oncology}

\begin{tabular}{l|l}
\hline Case Rep Oncol 2020;13:1463-1473 \\
\hline DOI: 10.1159/000510311 & $\begin{array}{l}\text { @ 2020 The Author(s). Published by S. Karger AG, Basel } \\
\text { www.karger.com/cro }\end{array}$ \\
\hline
\end{tabular}

Fernández-Ferreira et al.: Intergluteal Cleft Eccrine Porocarcinoma with Metastasis to Inguinal Region and Lung

\section{Conclusion}

This is the first reported case of intergluteal cleft EPC with metastasis to the left inguinal region and lung. Malignant sweat gland tumors are heterogeneous neoplasms of different biological behavior. The management of patients with metastatic EPC is difficult.

\section{Acknowledgment}

Thanks to the Southern Medical Hospital, for their support in data collection.

\section{Statement of Ethics}

The patient gave his informed written consent to publish his case (including the publication of images).

\section{Conflict of Interest Statement}

The authors have no conflicts of interest to declare.

\section{Funding Sources}

None.

\section{Author Contributions}

All authors thoroughly reviewed the topic.

\section{References}

1 Pinkus H, Mehregan AH. EPIDERMOTROPIC ECCRINE CARCINOMA. A CASE COMBINING FEATURES OF ECCRINE POROMA AND PAGET'S DERMATOSIS. Arch Dermatol 1963;88:597-606.

2 Robson A, Greene J, Ansari N, Kim B, Seed PT, McKee PH, et al. Eccrine porocarcinoma (malignant eccrine poroma): A clinicopathologic study of 69 cases. Am J Surg Pathol. 2001;25(6):710-20.

3 Chang 0, Elnawawi A, Rimpel B, Asarian A, Chaudhry N. Eccrine porocarcinoma of the lower extremity: A case report and review of literature. World J Surg Oncol. 2011;9:94.

4 Riera-Leal L, Guevara-Gutiérrez E, Barrientos-García JG, Madrigal-Kasem R, Briseño-Rodríguez G, TlacuiloParra A. Eccrine porocarcinoma: epidemiologic and histopathologic characteristics. Int J Dermatol. 2015; 54(5):580-6.

5 Skowron F, Poulhalon N, Balme B, Touzet S, Thomas L. [Primary eccrine porocarcinoma: a clinicopathological study of 50 cases]. Ann Dermatol Venereol, 2014;141(4):258-64.

6 Marone U, Caracò C, Anniciello AM, di Monta G, Chiofalo MG, Di Cecilia ML, et al. Metastatic eccrine porocarcinoma: Report of a case and review of the literature. World J Surg Oncol. 2011;9:32.

7 Song SS, Wu Lee W, Hamman MS, Jiang SI. Mohs micrographic surgery for eccrine porocarcinoma: An update and review of the literature. Dermatol Surg. 2015;41(3):301-6.

8 Bhat W, Akhtar S, Khotwal A, Platt AJ. Primary eccrine porocarcinoma of the finger with transit forearm and axillary metastasis. Ann Plast Surg. 2011;66(4):344-6.

9 González-López MA, Vázquez-López F, Soler T, Gómez-Diéz S, Garcia YH, Manjón JA, et al. Metastatic eccrine porocarcinoma: a 5.6-year follow-up study of a patient treated with a combined therapeutic protocol. Dermatol Surg. 2003;29(12):1227-32. 
Fernández-Ferreira et al.: Intergluteal Cleft Eccrine Porocarcinoma with Metastasis to Inguinal Region and Lung

10 Gutermuth J, Audring H, Voit C, Trefzer U, Haas N. Antitumour activity of paclitaxel and interferon-alpha in a case of metastatic eccrine porocarcinoma. J Eur Acad Dermatol Venereol. 2004;18(4):477-9.

11 Yamashita H, Kadono T, Tamaki K, Nakagawa K. Interesting response to concurrent chemoradiation in metastatic eccrine porocarcinoma. J Dermatol. 2008;35(9):606-7.

12 Gerber PA, Schulte KW, Ruzicka T, Bruch-Gerharz D. Eccrine porocarcinoma of the head: An important differential diagnosis in the elderly patient. Dermatology (Basel). 2008;216(3):229-33.

13 Fung YP. Eccrine porocarcinoma of the face. Hong Kong Dermatol Venereoly Bul. 1999;7(2):72-4.

14 Asghar AH, Mahmood H, Faheem M, Rizvi S, Khan KA, Irfan J. Porocarcinoma: A Rare Sweat Gland Malignancy. J Coll Physicians Surg Pak. 2009;19(6):389-90.

15 Rana R, Verma S, Puri V, Baliarsing A. Sweat gland tumor (Eccrine Porocarcinoma) of scalp: a rare tumor. Indian J Plast Surg. 2005;38(1):51-3.

16 Goon PKC, Gurung P, Levell NJ, Subramanian P, Yong ASW, Lee KYC, et al. Eccrine Porocarcinoma of the Skin is Rising in Incidence in the East of England. Acta Derm Venereol. 2018 Nov 5;98(10):991-2.

17 Á Abarzúa, S Álvarez-Véliz, C Moll-Manzur, Concomitant poroma and porocarcinoma, An. Bras Dermatol. 2017;92(4):550-2.

18 Mehregan AH, Hashimoto K, Rahbari H. Eccrine adenocarcinoma. A clinicopathologic study of 35 cases. Arch Dermatol. 1983;119(2):104-14.

19 Poiares Baptista A, Tellechea O, Reis JP, Cunha MF, Figueiredo P. [Eccrine porocarcinoma. A review of 24 cases]. Ann Dermatol Venereol. 1993;120(1):107-15.

20 Nazemi A, Higgins S, Swift R, In G, Miller K, Wysong A. Eccrine Porocarcinoma: New Insights and a Systematic Review of the Literature. Dermatol Surg. 2018 Oct;44(10):1247-61.

21 Grayson W, Loubser JS. Eccrine porocarcinoma of the penis. J Urol 2003;169, 2:611-2.

22 Shaw M, McKee PH, Lowe D, Black MM. Malignant eccrine poroma: a study of twenty-seven cases. Br J Dermatol. 1982;107(6):675-80.

23 Pal S, Phukan JP, Bose K, Saha A. Cytodiagnosis of Eccrine Porocarcinoma of the Scalp. Int J Trichology. 2017 Oct-Dec;9(4):184-6.

24 Parmar N, Mohamed M, Elmoghrabi A, McCann M Eccrine Porocarcinoma presenting as an abdominal wall mass in a patient with ulcerative colitis-A rare case report. Int J Surg Case Rep. 2016;23:40-3.

25 Choi SH, Kim YJ, Kim H, Kim HJ, Nam SH, Choi YW A rare case of abdominal porocarcinoma. Arch plast surg. 2014;41(1):91-3.

26 Val-Bernal JF, Hermana S. Vulvar eccrine porocarcinoma: report of a case and literature review. Rom J Morphol Embryol. 2017;58(4):1611-6.

27 Fujimine-Sato A, Toyoshima M, Shigeta S, Toki A, Kuno T, Sato I, et al. Eccrine porocarcinoma of the vulva: a case report and review of the literature. J Med Case Rep. 2016 Nov 10;10(1):319.

28 Adegboyega PA. Eccrine porocarcinoma of the vulva: a case report and review of literature. Int J Gynecol Pathol. 2011 Jan;30(1):95-100.

29 Iannicelli E, Galluzzo A, Salvi PF, Ziparo V, David V. A large porocarcinoma of perineal region: MR findings and review of the literature. Abdom Imaging. 2008 Nov-Dec;33(6):744-7.

30 Cursino FD, Teixeira L, Lima EA, Lima MA, Rodrigues SC, Takano D. Porocarcinoma: case report. An Bras Dermatol. 2011;86(6):1201-4

31 Cowden A, Dans M, Militello G, Junkins-Hopkins J, Van Voorhees AS. Eccrine porocarcinoma arising in two African American patients: distinct presentations both treated with Mohs micrographic surgery. Int J Dermatol. 2006;45(2):146-50.

32 Dewan P, Moir G, Cerio R, Harwood C. Aggressive eccrine porocarcinoma associated with haematological disorders: report of two cases. Clin Exp Dermatol. 2010;35(4):e207-9.

33 Maguire CA, Kazlouskaya V, Buchen D, Heller P, Elston DM Porocarcinoma with perineural invasion. Indian Dermatol Online J. 2015;6(2):122, 5.

34 Bleier BS, Newman JG, Quon H, Feldman MD, Kent KK, Weinstein GS. Eccrine porocarcinoma of the nose: case report and review of world literature. Arch Otolaryngol Head Neck Surg. 2006;132(2):215-8.

35 Boynton JR, Markowitch W. Porocarcinoma of the eyelid. Ophthalmology. 1997;104(10):1626-8.

36 Burra UK, Singh A, Saxena S. Eccrine porocarcinoma (malignant eccrine poroma): a case report. Dermatol Online J. 2005;11(2):17.

37 Chang NC, Tsai KB. Eccrine porocarcinoma of the auricle: a case report. Kaohsiung J Med Sci. 2009;25(7): 401-4.

38 D'amato M. Porocarcinoma of the heel. Am Cancer Soc. 1996;78:751-7.

39 D'Ambrosia R, Ward H, Parry E. Eccrine porocarcinoma of the eyelid treated with Mohs micrographic surgery. Dermatol Surg. 2004;30:570-1.

40 Evans J, Datta MW, Goolsby M, Langenstroer P. Eccrine porocarcinoma of the scrotum. Can J Urol. 2015;12(3): 2722-3.

41 Ioannidis S, Antoniou A, Patsatsi A, Kostogloudis N, Demiri E, Foroglou P. Eccrine porocarcinoma of the thumb in a patient with chronic exposure to benzene glue. J Hand Microsurg. 2015;7(1):157-60.

42 Jeon H, Smart C. An unusual case of porocarcinoma arising on the scalp of a 22-year-old woman. Am J Dermatopathol. 2015;37(3):237-9.

43 Jeon SP, Kang SJ, Jung SJ. Rapidly growing eccrine porocarcinoma of the face in a pregnant woman. J Craniofac Surg. 2014;25(2):715-7. 
44 Katsanis WA, Doering DL, Bosscher JR, O'Connor DM. Vulvar eccrine porocarcinoma. Gynecol Oncol. 1996; 62(3):396-9.

45 Liegl B, Regauer S. Eccrine carcinoma (nodular porocarcinoma) of the vulva. Histopathology. 2005;47(3): 324-6.

46 Mak ST, Li KK. Eccrine porocarcinoma of the eyelid in a non-Caucasian patient. Ophthal Plast Reconstr Surg. 2015;31(6):e166-8.

47 Masamatti S. Eccrine porocarcinoma of the scalp: a rare case report with review of literature. J Clin Diagn Res. 2016;10:15-6.

48 Melgandi W, Benson R, Hakin A, Bhasker S. Porocarcinoma scalp with high risk features treated with surgery and adjuvant radiotherapy: a case report and review of literature. J Egypt Natl Canc Inst. 2016;28(3):195-8.

49 Moussallem CD, Abi Hatem NE, El-Khoury ZN. Malignant porocarcinoma of the nail fold: a tricky diagnosis. Dermatol Online J. 2008;14(8):10.

50 Pal S. Eccrine porocarcinoma of scalp: a rare case report. Iranian J Pathol. 2015;10:588-91.

51 Perez-Garcia J, Morales R, Valverde CM, Rodon J, Suarez C, Semidey ME, et al. Eccrine porocarcinoma presenting with scrotal lymphedema: a case report and review of systemic treatment. Ann Oncol. 2010;21(4):907.

52 Permi HS, Bhat SP, Prasad H L K, Bhat VS. Eccrine porocarcinoma of scalp: an uncommon tumor at an unusual site. Indian J Surg Oncol. 2011;2(2):145-7.

53 Sheff JS, MacDougall DB. Unusual case of porocarcinoma of the foot with no clinically evident dermatologic manifestations. J Foot Ankle Surg. 2005;44(5):412-4.

54 Devi NR, Valarmathi K, Lilly M, Satish S, Mishra N. Primary axillary porocarcinoma: a rare cutaneous tumour. J Clin Diagn Res. 2016;10(2):ED04-6.

55 Watkins B, Urquhart AC, Holt JJ. Eccrine porocarcinoma of the external ear. Ear Nose Throat J. 2011;90(8): E25-7.

56 Lee HR, Jung GY, Shin HK, Lee DL, Lee JI, Kim JH Eccrine poroma of the postauricular area. Arch Craniofac Surg. 2017;18(1):44-5.

57 Raheemullah A, Allamaneni S, Weber S, Singh R. Eccrine porocarcinoma presenting as a hand cyst. J Hand Surg Am. 2016;41(11):e425-7.

58 Mishra P. Malignant eccrine poroma of the vulva : an intriguing case of a rare tumor at an unusual site Introduction. Indian J Dermatol. 2016;61:2016-8.

59 Erfurt-Berge C, Erdmann M, Brauner K, Bauerschmitz J. Eccrine porocarcinoma mimicking a venous leg ulcer. Int Wound J. 2016 Oct;13(5):1063-4.

60 Luz MA, Ogata DC, Montenegro MF, Biasi LJ, Ribeiro LC. Eccrine porocarcinoma (malignant eccrine poroma): a series of eight challenging cases. Clinics (Sao Paulo). 2010;65(7):739-42.

61 Snow SN, Reizner GT. Eccrine porocarcinoma of the face. J Am Acad Dermatol. 1992;27(2 Pt 2):306-11.

62 Vaidya KA, Shankarling M, Sukesh. Eccrine porocarcinoma of skin: a rare case report with review of literature. Sch J App Med Sci. 2014;2(1):125-7.

63 hhibber V, Lyle S, Mahalingam M. Ductal eccrine carcinoma with squamous differentiation: apropos a case. J Cutan Pathol. 2007;34:503-7.

64 De Giorgi V, Sestini S, Massi D, Papi F, Lotti T. Eccrine porocarcinoma: a rare but sometimes fatal malignant neoplasm. Dermatol Surg. 2007;33(3):374-7.

65 Mahalingam M, Richards JE, Selim MA, Muzikansky A, Hoang MP. An immunohistochemical comparison of cytokeratin 7 , cytokeratin 15 , cytokeratin 19 , CAM 5.2, carcinoembryonic antigen, and nestin in differentiating porocarcinoma from squamous cell carcinoma. Hum Pathol. 2012;43(8):1265-72.

66 van D, Nash JW, Prieto VG, Calonje E, Lyle S, Hafeez Diwan A, et al. Use of p63 expression in distinguishing primary and metastatic cutaneous adnexal neoplasms from metastatic adenocarcinoma to skin.J Cutan Pathol. 2007;34:474-80.

67 Akalin T, Sen S, Yücetürk A, Kandiloğlu G, P53 protein expression in eccrine poroma and porocarcinoma, Am J Dermatopathol. 2001;23(5):402-6.

68 Brown CW Jr, Dy LC. Eccrine porocarcinoma. Dermatol Ther. 2008;21(6):433-8.

69 Huet P, Dandurand M, Pignodel C, Guillot B. Metastasizing eccrine porocarcinoma: report of a case and review of the literature. J Am Acad Dermatol. 1996;35(5 Pt 2):860-4.

70 Rehal B, Merin MR, Barr K. Metastatic eccrine porocarcinoma. Cutis. 2013;92(2):67-70.

71 Mahomed F, Blok J, Grayson W. The squamous variant of eccrine porocarcinoma: a clinicopathological study of 21 cases. J Clin Pathol. 2008;61(3):361-5.

72 Lan CC, Yu HS, Liao WT, Hsu RC, Chung JC, Tsai KB, et al. Clear cell eccrine porocarcinoma with extensive cutaneous metastasis and peripheral lymphocyte dysfunction. Br J Dermatol. 2003;149(5):1059-63.

73 Kim JW, Oh DJ, Kang MS, Lee D, Hwang SW, Park SW A case of metastatic eccrine porocarcinoma. Acta Derm Venereol. 2007;87(6):550-2.

74 Montes-Torres A, Pérez-Plaza A, Llamas-Velasco M, Gordillo C, De Argila D, García-García C, et al. Eccrine porocarcinoma with extensive cutaneous metastases. Int J Dermatol. 2016;55(3):e156-60.

75 Wittenberg GP, Robertson DB, Solomon AR, Washington CV. Eccrine porocarcinoma treated with Mohs micrographic surgery: a report of five cases. Dermatol Surg. 1999;25(11):911-3.

76 Belin E, Ezzedine K, Stanislas S, lalanne N, Beylot-Barry M, Taieb A, et al. Factors in the surgical management of primary eccrine porocarcinoma: prognostic histological factors can guide the surgical procedure. $\mathrm{Br} \mathrm{J}$ Dermatol. 2011;165(5):985-9 


\section{Case Reports in Oncology}

\begin{tabular}{l|l}
\hline Case Rep Oncol 2020;13:1463-1473 \\
\hline DOI: 10.1159/000510311 & $\begin{array}{l}\text { ○ 2020 The Author(s). Published by S. Karger AG, Basel } \\
\text { www.karger.com/cro }\end{array}$ \\
\hline
\end{tabular}

Fernández-Ferreira et al.: Intergluteal Cleft Eccrine Porocarcinoma with Metastasis to Inguinal Region and Lung

77 Günhan O, Karslioğlu Y, Alömeroğlu M, Berberoğlu U. Eccrine porocarcinoma: a case with an obscure primary tumor diagnosed from lymph node metastasis. Am J Dermatopathol. 2007;29(2):176-9.

78 Xu YG, Aylward J, Longley BJ, Hinshaw MA, Snow SN. Eccrine Porocarcinoma Treated by Mohs Micrographic Surgery: Over 6-Year Follow-up of 12 Cases and Literature Review. Dermatol Surg. 2015;41(6):685-92.

79 Tolkachjov SN, Hocker TL, Camilleri MJ, Baum CL. Treatment of porocarcinoma with Mohs micrographic surgery. Dermatol Surg. 2016;42(6):745-50.

80 Tidwell WJ, Mayer JE, Malone J, Schadt C, Brown T. Treatment of eccrine porocarcinoma with Mohs micrographic surgery: a cases series and literature review. Int J Dermatol. 2015;54(9):1078-83.

81 Wildemore JK, Lee JB, Humphreys TR. Mohs surgery for malignant eccrine neoplasms. Dermatol Surg. 2004; 30(12 Pt 2):1574-9.

82 Pinheiro R, Oliveira A, Mendes-Bastos P. Dermoscopic and reflectance confocal microscopic presentation of relapsing eccrine porocarcinoma. J Am Acad Dermatol. 2017;76(2S1):S73-5.

83 Vleugels FR, Girouard SD, Schmults CD, Ng AK, Russell SE, Wang LC, et al. Metastatic eccrine porocarcinoma after Mohs micrographic surgery: a case report. J Clin Oncol. 2014;30(21):e188-91.

84 Shiohara J, Koga H, Uhara H, Takata M, Saida T. Eccrine porocarcinoma: Clinical and pathological studies of 12 cases. J Dermatol. 2007;34(8):516-22.

85 Nguyen A, Nguyen AV. Eccrine porocarcinoma: a report of 2 cases and review of the literature. Cutis. 2014 93(1):43-6.

86 Bogner PN, Fullen DR, Lowe L, Paulino A, Biermann JS, Sondak VK, et al. Lymphatic mapping and sentinel lymph node biopsy in the detection of early metastasis from sweat gland carcinoma. Cancer. 2003;97(9): 2285-9.

87 Gómez-Zubiaur A, Medina-Montalvo S, Vélez-Velázquez MD, Polo-Rodríguez I. Eccrine Porocarcinoma: Patient Characteristics, Clinical and Histopathologic Features, and Treatment in 7 Cases. Actas Dermosifiliogr. 2017; 108(4):e27-32.

88 Kurashige Y, Minemura T, Nagatani T. Eccrine porocarcinoma: clinical and pathological report of eight cases. Case Rep Dermatol. Oct 2013;5(3):259-66.

89 Ishida M, Hotta M, Kushima R, Okabe H. A case of porocarcinoma arising in pigmented hidroacanthoma simplex with multiple lymph node, liver and bone metastases. J Cutan Pathol Feb 2011;38(2):227-31.

90 Mandaliya H, Nordman I. Metastatic eccrine porocarcinoma: a rare case of successful treatment. Case Rep Oncol. Aug 2016;9(2):454-6.

91 Joseph D, Dubashi B, Basu D, Srinivasan S, Jain A. Response to taxane-based chemotherapy in metastatic eccrine porocarcinoma with extensive cutaneous involvement. Indian J Cancer. Mar 2015;52(1):73-4.

92 Godillot C, Boulinguez S, Riffaud L, Sibaud V, Chira C, Tournier E, et al. Complete response of a metastatic porocarcinoma treated with paclitaxel, cetuximab and radiotherapy. Eur J Cancer. 2018 Feb;90:142-5.

93 Kim JW, Oh DJ, Kang MS, Lee D, Hwang SW, Park SW. A case of metastatic eccrine porocarcinoma. Acta Derm Venereol. 2007;87(6):550-2.

94 Grimme H, Petres A, Bergen E, Wiemers S, Schöpf E, Vanscheidt W. Metastasizing porocarcinoma of the head with lethal outcome. Dermatology (Basel). 1999;198(3):298-300.

95 Shiohara J, Koga H, Uhara H, Takata M, Saida T. Eccrine porocarcinoma: clinical and pathological studies of 12 cases. J Dermatol. Aug 2007;34(8):516-22.

96 Permal S, Chemal N, Dhote R, Palangie A, Christoforov B. [Lung neoplasms revealing a rare cutaneous tumor: eccrine porocarcinoma]. Rev Med Interne. Jan 2000;21(1):91-4.

97 Plunkett TA, Hanby AM, Miles DW, Rubens RD. Metastatic eccrine porocarcinoma: response to docetaxel (Taxotere) chemotherapy. Ann Oncol. Mar 2001;12(3):411-4.

98 Swanson JD Jr, Pazdur R, Sykes E. Metastatic sweat gland carcinoma: Response to 5-fluorouracil infusion. J Surg Oncol. 1989;42(1):69-72.

99 de Bree E, Volalakis E, Tsetis D, Varthalitis Y, Panagiotidis J, Romanos J, et al. Treatment of advanced malignant eccrine poroma with locoregional chemotherapy. Br J Dermatol. 2005;152(5):1051-5.

100 Kaseb H, Babiker HM. Cancer, an overview of eccrine carcinoma. In: StatPearls. Treasure Island (FL): StatPearls Publishing; 2020.

101 Seo BF, Choi HJ, Jung SN. Eccrine porocarcinoma on the cheek. Arch Craniofac Surg. 2019;20(1):48-50.

102 Khaja M, Ashraf U, Mehershahi S, Ayyadurai P, Malik S. Recurrent Metastatic Eccrine Porocarcinoma: A Case Report and Review of the Literature. Am J Case Rep. 2019;20:179-83.

103 Shen J, Pan X, Lu Y, Pan D, Ma Y, Zhan R. A case of eccrine porocarcinoma characterized by a progressive increase in the level of Ki-67 index: case report and review of literature. BMC Surg. 2019;19(1):142.

104 Coonley CJ, Schauer P, Kelsen DP, Sordillo P, Huvos AG. Chemotherapy of metastatic sweat gland carcinoma. A retrospective review. Am J Clin Oncol. 1985;8(4):307-11. 